Al Maal : Journal of Islamic Economics and Banking

http://jurnal.umt.ac.id/index.php/jieb

E-ISSN : $2580-3816$

Vol : 2 No. 1 Bulan Juli Tahun 2020

Hlm : $81-97$

DOI : $\quad 10.31000 /$ almaal.v2i1.2741

\title{
Kebijakan Penanganan Pembiayaan Bermasalah pada Bank Syariah dan Konvensional Perspektif Ekonomi Syariah Pasca Bencana di Sulawesi Tengah
}

\author{
Syaakir Sofyan ${ }^{1 *}$ \\ ${ }^{1}$ Prodi Perbankan Syariah, Fakutas Ekonomi dan Bisnis Islam IAIN Palu,Sulawesi Tengah, \\ Indonesia \\ *baangsofyan@gmail.com
}

\begin{abstract}
The natural disaster that occurred in Palu on September 28, 2018 was an earthquake that occurred due to the Palu Koro fault activity, which had a magnitude of 7.4 on the Richter scale, which had an impact on bank performance, primarily related to non-performing loans (NPLs). The purpose of this study was to determine the policy of handling non-performing loans for disaster victims as well as an analysis of the Islamic economy of the policy. This research belongs to the category of qualitative research with a descriptive analysis approach. The object under study is Islamic and conventional banks. The handling of problem loans still has several things that need to be clarified, especially for write offs and write offs that are not regulated in OJK Regulation No. 45/POJK.03/2017 concerning Special Treatment of Credit or Financing for Certain Areas in Indonesia Affected by Natural Disasters. In addition, the determination of credit quality and restructuring with a period of 3 years in special treatment for areas affected by natural disasters is too early to be determined, because the impact of natural disasters for each customer is different and allows some customers to make bad intentions by utilizing the situation to avoid payment.
\end{abstract}

Keywords: Bank; Islamic Economics; NPL; Restructurisation.

\section{ABSTRAK}

Bencana alam yang terjadi di Palu pada 28 September 2018 merupakan peristiwa gempa bumi yang terjadi akibat aktivitas di zona besar Palu Koro yang berkekuatan 7,4 skala Richter memberikan dampak terhadap kinerja bank, utamanya terkait non performing loan (NPL) yang diakibatkan ketidakmampuan debitur. Tujuan penelitian ini adalah untuk mengetahui kebijakan penanagan kredit bermasalah bagi korban bencana serta analisis ekonomi Islam terhadap kebijakan tersebut. Penelitian ini termasuk kategori penelitian kualitatif dengan pendekatan analisis deskriptif. Obyek yang diteliti adalah bank syariah dan konvensional. Penanganan kredit bermasalah masih terdapat beberapa hal yang perlu diperjelas utamanya bagi hapus buku dan hapus tagih yang tidak diatur dalam Peraturan OJK Nomor 45/POJK.03/2017 tentang Perlakuan Khusus terhadap Kredit atau Pembiayaan bagi Daerah Tertentu di Indonesia yang Terkena Bencana Alam. Selain itu, penetapan kualitas kredit dan resktrukturisasi dengan masa 3 tahun dalam perlakuan khusus bagi daerah yang terkena bencana alam sangat terlalu dini untuk ditetapkan mengingat karena dampak bencana alam bagi setiap nasabah berbeda-beda dan memungkinkan sebagian nasabah melakukan iktikad kurang baik dengan memanfaatkan situasi untuk menghindari pembayaran.

Kata kunci : Bank; Ekonomi Islam; NPL; Restrukturisasi. 


\section{Pendahuluan}

Bank merupakan agen pembangunan, karena semua bank berfungsi sebagai intermediasi antara pihak yang memiliki modal untuk berproduksi, sehingga dengan bantuan modal bagi para pengusaha, sektor riil perekenomian akan berkembang. Lembaga keuangan memainkan dua peran yang sangat diperlukan dalam sistem keuangan, yaitu memberikan dukungan untuk berbagai pasar keuangan serta berperan sebagai penyedia solusi keuangan di mana kegagalan pasar ada meskipun ada lembaga pendukung pasar (El-Gamal, 2006). Dengan demikian, pengelolaan bank harus dilakukan secara hati-hati, karena bank merupakan lembaga usaha yang tidak dapat terlepas dari risiko (Hodgman, 1960). Kredit bermasalah merupakan kredit tidak lancar yang diberikan kepada pihak bank kepada nasabah yang tidak dapat memenuhi kewajibannya untuk membayar kembali dana yang dipinjamnya secara penuh pada saat jatuh tempo. Pembiayaan yang tidak lancar harus secepatnya diselesaikan agar kerugian yang lebih besar dapat dihindari.

Bencana alam yang terjadi di Palu pada 28 September 2018 merupakan peristiwa gempa bumi yang terjadi akibat aktivitas di zona besar Palu Koro yang berkekuatan 7,4 skala Richter dan diikuti dengan tsunami yang melanda Pantai Barat Pulau Sulawesi, serta likuifaksi pada daerah-daerah tertentu dengan korban 2.045 tewas. Kondisi perekonomian lumpuh akibat bencana tersebut sehingga seluruh aktivitas keuangan terhambat termasuk perbankan. Dampak dari bencana tersebut menyebabkan bank tidak dapat melaksanakan operasional sebagaimana mestinya. Hal demikian pula terjadi pada masyarakat yang tertimpa oleh dampak bencana tersebut yang bukan hanya bersifat materi, namun termasuk non materi.

Dampak dari bencana tersebut menyebabkan potensi non performing loan atau yang biasa disebut dengan kredit bermasalah di berikan kepada wilayah tersebut. Hal ini terjadi bukan dikarenakan ada faktor kesengajaan, namun diakibatkan oleh faktor lain yang tidak terduga seperti bencana alam yang berdampak langsung kepada usaha debitur.

Menurut Wimbih Santoso selaku Ketua Dewan Komisioner Otorisas Jasa Keuangan (OJK), OJK memperkirakan potensi NPL di Sulawesi Tengah akibat bencana mencapai Rp. 4.063 triliun dari total Rp. 27 triliun kredit yang disalurkan industri jasa keuangan dan angka tersebut hanya setara dengan $0,5 \%$ jumlah kredit nasional senilai.Dampak terbesar yang merasakan adalah bank umum yang mencapai Rp. 3,9 triliun dari 20.918 rekening, kemudian bank umum syariah yang mencapai Rp. 246,9 miliar, dan bank swasta nasional mencapai Rp. 541 miliar. Selain itu potensi NPL juga terjadi pada BPR yang mencapai Rp. 6,1 miliar.

Dalam kondisi tersebut, resiko kredit tidak hanya dilatarbelakangi oleh faktor ketidakmampuan atan ketidamauan membayar debirut dalam keadaan normal, namun terdapat faktor lain dan tidak terduga yang berdampak langsung pada kelangsungan usaha debitur. Dengan demikian, OJK menetapkan relaksasi kredit nasabah dalam rangka membanu penulihan usaha debitur dan perbankan sekaligus membantu kondisi perekonomian wilayah yang terkena dampak bencana alam.

Berdasarkan latar belakang di atas, maka tulisan ini menganalisis kebijakan penanganan kredit bermasalah bagi korban gempa, tsunami, dan likuifaksi serta dalam tinjauan ekonomi syariah 


\section{KAJIAN LITERATUR Kredit Bermasalah}

Kredit bermasalah atau biasa disebut Non Performing Loan (NPL) merupakan resiko yang terkandung dalam setiap pemberian kredit oleh bank (Sutarno, 2003). Risiko tersebut berupa keadaan dimana kredit tidak dapat kembali tepat pada waktunya yang disebabkan oleh beberapa faktor (Ais, 2005). NPL merupakan kendala utama bagi pengembangan sektor perbankan dan menjadi indikator atas kinerja bank (Zhang, Cai, Dickinsin, Kutan, 2016; Saba, Kouser, \& Azzem, 2012; Beaton \& Lyrvoda, 2016). Sekalipun bank dalam memberikan kredit tidak pernah menginginkan bahwa kredit yang diberikan akan menjadi kredit yang bermasalah, dan untuk keperluan tersebut bank akan melakukan segala cara bersifat preventif yang tujuannya adalah untuk mencegah agar kredit tidak bermasalah (Gazali \& Usman, 2012) dengan cara memverifikasi segala bentuk pengajuan dalam perspektif manajemen resik (Haneef \& Riaz, 2012).

Ada beberapa pengertian kredit bermasalah (Rivai, Veithza, 2006), yaitu:

1. Kredit yang di dalam pelaksanaannya belum mencapai/memenuhi target yang diinginkan oleh pihak bank;

2. Kredit yang memiliki kemungkinan timbulnya resiko di kemudian hari bagi bank dalam arti luas;

3. Mengalami kesulitan di dalam penyelesaian kewajiban-kewajibannya, baik dalam bentuk pembayaran kembali pokoknya dan atau pembayaran bunga, denda keterlambatan serta ongkos-ongkos bank yang menjadi beban nasabah yang bersangkutan;

4. Kredit di mana pembayaran kembalinya dalam bahaya, terutama apabila sumbersumber pembayaran kembali yang diharapkan diperkirakan tidak cukup untuk membayar kembali kredit, sehingga belum mencapai/ memenuhitarget yang diinginkan oleh bank;

5. Kredit di mana terjadi cidera janji dalam pembayaran kembali sesuai perjanjian, sehingga terdapat tunggakan, atau ada potensi kerugian di perusahaan nasabah sehingga memiliki kemungkinan timbulnya resiko di kemudian hari bagi bank dalam arti luas;

6. Mengalami kesulitan di dalam penyelesaian kewajiban-kewajibannya terhadap bank, baik dalam bentuk pembayaran kembali pokoknya, pembayaran bunga, pembayaran ongkos-ongkos bank yang menjadi beban nasabah-nasabah yang bersangkutan;

7. Kredit golongan perhatian khusus, kurang lancar, diragukan dan macet serta golongan lancar yang berpotensi menunggak.

Biety dan Karen Cak menyebut kredit bermasalah sebagai kredit lalai yang pembayaran angsuran (pokok dan bunga) tidak dibayar sesuai dengan perjanjian kredit dan akan dilaporkan sebagai kredit lalai bergantung pada jadwal angsuran kredit (Biety \& Nerderkohr, 2008). Penyebab terjadinya kredit bermasalah diantaranya dapat melalui berasal dari internal perbankan yang dalam melakukan analisis, pihak analisis kurang teliti dan salah dalam melakukan perhitungan. Selain itu, dapat pula berasal dari peminjam yang memiliki unsur kesengajaan untuk tidak membayar kewajibannya kepada bank sehingga kredit yang diberikan macet serta unsur tidak sengaja yang berarti si debitur memiliki keinginan untuk membayar namun tidak mampu, serta faktor luar yang 
diantranya adalah bencana alam, krisis ekonomi, harga komoditas jatuh, harga-harga kebutuhan melonjak, dan regulasi pemerintah (Salas \& Sauruna, 2002; Clair \& Tucker, 1993; Mackenzir, 2011).

Selanjutnya untuk menentukan berkualitas atau tidaknya suatu kredit diberikan ukuran-ukuran tertentu dan Bank Indonesia menggolongkan kualitas kredit menurut Surat Edaran Bank Indonesia Nomor 7/3/DPNP Tanggal 31 Januari 2005 Perihal Kualitas Aktiva Bank Umum sebagai berikut:

\section{Tabel 1. Penilaian Kualitas Kredit}

\begin{tabular}{|c|c|}
\hline Kategori & Indikator \\
\hline Lancar (Pass) & $\begin{array}{l}\text { kredit yang memenuhi kriteria industri atau kegiatan usaha yang } \\
\text { memiliki potensi pertumbuhan yang baik, perolehan laba tinggi dan } \\
\text { stabil, pembayaran tepat waktu, perkembangan rekening baik dan } \\
\text { tidak ada tunggakan serta sesuai persyaratan kredit. }\end{array}$ \\
\hline $\begin{array}{l}\text { Dalam } \\
\text { Khusus } \\
\text { Mention) }\end{array}$ & $\begin{array}{l}\text { kredit yang memenuhi kriteria: industri atau kegiatan usaha } \\
\text { memiliki potensi pertumbuhan yang terbatas, perolehan laba cukup } \\
\text { lancar baik, namun memiliki potensi menurun, terdapat tunggakan } \\
\text { pembayaran pokok dan/atau bunga sampai } 90 \text { hari ( } 3 \text { bulan). }\end{array}$ \\
\hline $\begin{array}{l}\text { Kurang Lancar } \\
\text { (Substandard) }\end{array}$ & $\begin{array}{l}\text { kredit yang memenuhi kriteria: industri atau kegiatan usaha } \\
\text { menunjukkan potensi pertumbuhan yang sangat terbatas atau tidak } \\
\text { mengalami pertunbuhan, perolehan laba rendah, terdapat } \\
\text { tunggakan pembayaran pokokdan/atau bunga yang telah melampaui } \\
90 \text { hari sampai dengan } 120 \text { hari. }\end{array}$ \\
\hline Diragukan (Doubtful) & $\begin{array}{l}\text { kredit yang memenuhi kriteria: industri atau kegiatan usaha } \\
\text { menurun, laba sangat kecil dan negatif, kerugian operasional } \\
\text { dibiayai dengan penjualan aset, terdapat tunggakan pembayaran } \\
\text { pokok dan/atau bunga yang telah melampaui } 120 \text { hari sampai } \\
\text { dengan } 180 \text { hari. }\end{array}$ \\
\hline Macet (Loss) & $\begin{array}{l}\text { kredit yang memenuhi kriteria: kelangsungan usaha sangat } \\
\text { diragukan, industri mengalami penurunan dan sulit untuk pulh } \\
\text { kembali, kemungkinan besar kegiatan usaha akan terhenti, } \\
\text { mengalami kerugian yang besar, debitur tidak mampu memenuhi } \\
\text { seluruh kewajiban dan kegiatan usaha tidak dapat dipertahankan, } \\
\text { terdapat tunggakan pembayaran pokok dan/ atau bunga yang telah } \\
\text { melampaui } 180 \text { hari. }\end{array}$ \\
\hline
\end{tabular}

Sumber: Bank Indonesia

Adapun kebijakan dalam penyelematan kredit macet yaitu:

1. Rescheduling (penjadwalan kembali), merupakan upaya pertama dari pihak bank untuk menyelamatkan kredit yang diberikannya kepada debitur (Crawford, 1987). Cara ini dilakukan jika ternyata pihak debitur tidak mampu untuk memenuhi kewajibannya dalam hal pembayaran kembali angsuran pokok maupun bunga kredit. Rescheduling adalah penjadwalan kembali sebagian atau seluruh kewajiban debitur (Lanoei, Lemarbre, 1996; Georgievska, 2008)..

2. Reconditioning merupakan usaha pihak bank untuk menyelamatkan kredit yang diberikannya dengan cara mengubah sebagian atau seluruh kondisi (persyaratan) yang semula disepakati bersama pihak debitur dan dituangkan dalam perjanjian kredit. 
3. Restructuring adalah usaha penyelamatan kredit yang terpaksa harus dilakukan bank dengan cara mengubah komposisi pembiayaan yang mendasari pemberian kredit (Yildirim \& Philippatos, 2007). Pembiayaan suatu proyek atau bisnis tidak seluruhnya berasal dari modal (dana) sendiri, tetapi sebagian besar dibiayai dengan kredit yang diperoleh dari bank.

Dalam Peraturan Bank Indonesia Nomor Nomor 14/15/PBI/2012 tentang Kualitas Aset Bank Umum disebutkan pada pasal 1 bahwa resktrukturisasi kredit adalah upaya yang dilakukan bank dalam kegiatan perkreditan terhadap debitur yang mengalami kesulitan untuk memenuhi kewajibannya yang dilakukan antara lain:

1. Penurunan suku bunga kredit

2. Perpanjangan suku bunga waktu kredit

3. Pengurangan tunggakan bunga kredit

4. Pengurangan tunggakan pokok kredit

5. Penambahan fasilitas kredit

6. Konversi kredit menjadi penyertaan modal sementara.

Adapun penyelesaian kredit bermasalah di Indonesia dapat dikatakan merupakan langkah terakhir yang dapat dilakukan setelah langkah-langkah penyelematan di atas berupa restrukturisasi tidak efektif lagi. Dikatakan sebagai langkah terakhir karena penyelesaian kredit bermasalah melalui lembaga hukum memang memerlukan waktu yang relatif lama, dan bila melalui badan hukum maka kepastian hukum tetap dan dapat pula melalui lembaga yang berkompeten dalam membantu menyelesaikan kredit . Dalam penyelesaian kredit bermasalah, biasanya dilakukan melalui Badan Urusan Piutang dan Lelang Negara (BUPLN), proses litigasi di pengadilan, dan arbitrase (Ais, 2005).

\section{Ekonomi Islam}

Para pakar mengemukakan definisi dari ekonomi Islam diantaranya adalah:

1. Abdul Manan mendefiniskan ekonomi Islam adalah ilmu pengetahuan sosial yang mempelajari masalah-masalah ekonomi masyarakat yang diilhami oleh nilai-nilai Islam (Manan, 1980).

2. Menurut Hasanuz Zaman mendefinisikan ekonomi Islam membutuhkan beberapa prasyarat yang merupakan ciri khas cara hidup Islam yaitu dalam Islam kegiatan ekonomi seharusnya tidak diatur oleh keinginan dan pengalaman manusia saja, akan tetapu harus diatur oleh perintah dasar syari'at. Sebagai ilmu sosial, ekonomi Islam tidak terlepas dari nilai-nilai moral. Aspek normatifnya lebih menonjol daripada aspek positifnya yang berperan dalam menganalisis fenomena ekonomi yang ada dan dalam memutuskan tindakan yang tepat sesuai dengan tujuan Islam. Syariah telah menetapkan tujuan-tujuan yang harus diusahakan oleh seorang individu maupun masyarakat. Ekonomi Islam adalah pengetahuan dan penerapan perintah dan aturan syariah yang mencegah ketidakadilan dalam perolehan dan pembuangan sumber daya material untuk memberikan kepuasan kepada manusia dan memungkinkan mereka untuk melakukan kewajiban mereka kepada Allah dan masyarakat (Zaman, 1984). 
3. Akram Khan mengemukakan ekonomi Islam bertujuan mempelajari falah manusia yang dicapai dengan mengusahakan sumber daya bumi atas dasar kerja sama dan partisipasi (Arif, 1985).

4. Menurut Syed Nawab Haider Naqvi, ilmu ekonomi Islam, singkatnya, merupakan kajian tentang perilaku ekonomi orang Islam representatif dalam masyarakat muslim modern (Naqvi, 2009).

Para pemikir ekonomi Islam berbeda pendapat dalam memberikan kategorisasi terhadap prinsip-prinsip ekonomi Islam. Ekonom Islam modern seperti Khurshid Ahmad telah mengembangkan pendekatan multidisiplin dan multidimensi yang membentuk landasan konseptual ekonomi Islam dimana standar etika dan moral Islam terintegrasi erat dengan motif ekonomi. Berlawanan dengan ekonomi konvensional, pendekatan Islam modern ini menghadirkan visi sosio-etis ekonomi untuk memecahkan masalah ekonomi manusia. Ekonomi Islam bertujuan untuk mengembangkan sistem baru berdasarkan fitur-fitur berikut: (i) ekonomi Islam adalah sub-sistem dari domain yang lebih besar dari agama Islam, oleh karena itu sumbernya berasal dari sumber fundamental Islam; (ii) ini berurusan dengan semua masalah ekonomi dan kegiatan seperti dalam kasus sistem ekonomi yang berlaku; dan (iii) mewajibkan individu untuk membatasi pilihan mereka dalam batasan etika Islam. Khursid Ahmad memandang ekonomi Islam didasarkan pada aksioma konseptual yaitu tauhid, rububiyyah, khilafah, dan tazkiyah (Nabi, 2016).

M. Umer Chapra mengemukakan prinsip dasar ekonomi Islam yang tidak hanya membingkai pandangan dunia Islam, tetapi juga memberikan sumber utama maqashid syariah dan strategi pengembangan (Chapra, 1995), yaitu:

1. Tauhid

Landasan agama Islam adalah tauhid (Keesaan) yang pada konsep ini terletak seluruh pandangan dan strateginya. Segala sesuatu berasal dari-Nya dan ini berarti bahwa alam semesta telah dirancang dan diciptakan oleh Yang Maha Tinggi, dan tidak muncul secara kebetulan atau kebetulan. Segala sesuatu yang diciptakan-Nya memiliki tujuan yang memberikan makna bagi eksistensi Semesta dan manusia menjadi bagian dari hal tersebut.

\section{Khilafah}

Manusia adalah khalifah di bumi dan telah diberkahi dengan semua karakteristik spiritual dan mental, serta sumber daya material, untuk memungkinkannya menjalankan misi secara efektif. Dalam kerangka acuan khilafahnya, manusia bebas dan juga mampu berpikir dan bernalar, untuk memilih di antara benar dan salah, adil dan tidak adil, dan untuk mengubah kondisi hidupnya.

Sumber daya yang diberikan Tuhan kepada dunia ini tidak terbatas. Namun mereka cukup untuk memenuhi kesejahteraan manusia. Manusia bebas untuk memilih antara penggunaan alternatif sumber daya ini. Salah satu ujian sebenarnya terletak pada pemanfaatan sumber daya yang diberikan Tuhan dalam suatu 'efisien' dan 'adil' agar kesejahteraan (falah) semua terjamin. Status khalifah dalam Islam sebagai pengemban amanat sangat penting dalam perekonomian. Peran utamanya adalah untuk menjamin perekonomian agar berjalan sesuai dengan syariah, dan untuk memastikan tidak terjadi pelanggaran terhadap hak-hak manusia. 
3. Keadilan

Persaudaraan, yang merupakan bagian integral dari konsep tauhid dan khilafah akan tetap menjadi konsep kosong yang tidak memiliki substansi jika tidak disertai dengan keadilan sosial ekonomi. Keadilan telah dipegang oleh para ahli hukum untuk menjadi unsur yang mutlak diperlukan dari maqasid al-Shari'ah, sejauh ini sehingga tidak mungkin untuk membayangkan masyarakat yang ideal di mana keadilan belum ditetapkan. Islam sama sekali tidak ambigu dalam tujuannya memberantas masyarakat manusia dari semua jejak zulm, yang merupakan istilah Islam komprehensif yang merujuk pada semua bentuk ketidakadilan, eksploitasi, penindasan, dan kesalahan, di mana seseorang merampas hak orang lain atau tidak memenuhi kewajibannya terhadap mereka

Menurut Maulana Maududi prinsip dasar sistem ekonomi Islam adalah: kepemilikan pribadi, batasan halal dan haram, kesetaraan ekonomi, ekonomi bebas dan peran kesejahteraan negara. Sistem ini didirikan untuk mencapai tujuan kebebasan manusia, pengembangan material dan moral yang dilakukan secara simultan, penegakan keadilan, pemerataan kekayaan, pemenuhan kebutuhan dasar manusia, dan koordinasi antara berbagai kelompok masyarakat (Aziz \& Mahmud, 2009).

\section{METODE PENELITIAN}

Penelitian ini termasuk dalam kategori penelitian kualitatif dengan pendekatan analisis deskriptif. Penelitian kualitatif merupakan metode yang digunakan untuk meneliti kondosi obyek secara alamiah, dimana peneliti sebagai instrumen kunci (Sugiyono, 2009) dengan memanfaatkan berbagai metode alami (Moleong, 2014). Adapun obyek yang diteliti adalah institusi keuangan yaitu bank syariah dan konvensional. Tipe data adalah data kualitatif yang terdiri dari sumber data primer dan sekunder. Teknik pengumpulan data menggunakan teknik observasi dan dokumentasi dengan teknik analisis data menggunakan teknik yang kemukakan oleh Miles dan Huberman yaitu reduksi data, tampilan data, dan kesimpulan/verifikasi data (Emzir, 2010).

\section{HASIL DAN PEMBahasan}

\section{Kebijakan Penanganan Pembiayaan Bermasalah pada Bank Syariah dan Konvensional pasca Bencana}

Indonesia sebagai negara kepulauan yang dikenal sebagai zamrud khatulistiwa. Namun dibalik kekayaan juga tersimpan potensi gerakan alam yang dapat menimbulkan bencana. Hal tersebut tidak terlepas dari kenyataan bahwa wilayah nusantara ini tidak hanya dikelilingi oleh tiga lempeng aktif tektonik, tetapi juga berada pada cincin api (ring of fire) dan menengah yang memberikan dampak negatif bagi kehidupan masyarakat.

Dampak yang diperoleh dari bencana meliputi banyak aspek dalam kehidupan masyarakat termasuk pula pada industri jasa keuangan. OJK sebagai lembaga yang berfungsi menyelenggarakan sistem pengaturan dan pengawasan terhadap keseluruhan kegiatan di dalam sektor jasa keuangan, mengeluarkan Peraturan OJK Nomor 45/POJK.03/2017 tentang Perlakuan Khusus terhadap Kredit atau Pembiayaan bagi Daerah Tertentu di Indonesia yang Terkena Bencana Alam. Peraturan ini memberikan perlakuan khusus terhadap kredit atau pembiayaan bank berupa penetapan kualitas kredit atau pembiayaan dan terhadap pemberian kredit atau pembiayaan yang diberikan setelah terjadinya bencana alam kepada debitur yang terkena dampak bencana alam. 
Adapun penentuan daerah yang terkena bencana alam dalam suatu keputusan Dewan Komisioner OJK dalam Peraturan Otorisas Jasa Keuangan Nomor 45/POJK.03/2017 tentang Perlakuan Khusus terhadap Kredit atau Pembiayaan Bank bagi Daerah Tertentu di Indonesia yang Terkena Bencana Alam dengan memperhatikan:

1. Aspek luas wilayah yang terkena bencana alam

2. Jumlah korban jiwa

3. Jumlah kerugian materil

4. Jumlah debitur yang diperkirakan terkena dampak bencana alam,

5. Persentase jumlah kredit atau pembiayaan yang diberikan kepada debitur yang terkena dampak bencana alam terhadap jumlah kredit atau pembiayaan di daerah bencana alam

6. Persentase jumlah kredit atau pembiayaan dengan plafon sampai dengan Rp. 5 milyar terhadap jumlah kredit atau pembiayaan di daerah terkena bencana

7. Aspek lainnya yang menurut OJK perlu untuk dipertimbangkan.

Adapun perlakuan khusus terhadap kredit/pembiayaan pasca bencana gempa, tsunami, dan likuifaksi di Pasigala adalah tepatnya pada tanggal 10 Oktober 2018 pasca gempa, tsunami, dan likuifaksi Pasigala, Dewan Komisioner OJK menetapkan kebijakan pemberian perlakuan khusus terhadap kredit dan pembiayaan bank syariah perbankan untuk debitur atau proyek yang berada di lokasi bencana alam di Provinsi Sulawesi Tengah yang diputuskan pada Rapat Dewan Komisioner OJK pada hari Selasa (9/10/2018) di Bali. Lihat Siaran Pers Perlakuan Khusus Terhadap Nasabah dan Industri Jasa Keuangan yang Terdampak Bencana di Provinsi Sulawesi Tengah, 10 Oktober 2018. Perlakuan khusus tersebut diberikan untuk penilaian kredit/pembiayaan syariah, restrukturisasi, dan atau pemberian kredit/pembiayaan syariah baru di Kota Palu, Kabupaten Donggala, dan Kabupaten Sigi Provinsi Sulawesi Tengah yang mengacu pada POJK 45/POJK.03/2017 tentang Perlakuan Khusus terhadap Kredit atau Pembiayaan Bank bagi Daerah Tertentu di Indonesia yang Terkena Bencana Alam dan akan berlaku selama tiga tahun terhitung sejak tanggal ditetapkan.

Secara umum perlakuan khusus bagi bank konvensional dan syariah adalah sama, namun pada kebijakan yang dikeluarkan oleh OJK diberikan penekanan lebih terhadap perlakuan untuk bank syariah yaitu dengan menambahkan poin khusus dalam kebijakan tersebut. Adapun isinya adalah perlakuan khusus terhadap daerah yang terkena dampak juga berlaku bagi penyediaan dana berdasarkan prinsip syariah yang mencakup seluruh jenis pembiayaan. adalah:

Adapun perlakuan khusus terhadap kredit pada bank konvensional dan syariah

\section{Penilaian Kualitas Kredit}

Perlakuan khusus atas penilaian kualitas kredit dengan plafon maksimal Rp. 5 milyar didasarkan atas ketetapan membayar pokok dan/atau bunga. Adapun bagi kredit dengan plafon di atas Rp. 5 milyar penetapan kualitas kreditnya mengacu pada PBI Nomor 14/15/PBI/2012 tentang Penilaian Kualitas Aset Bank Umum. Hal ini berbeda saat keadaan normal untuk plafon maksimal Rp. 5 milyar (perlakuan khusus) yang mengharuskan penentuan kualitas kredit dan penyediaan dana lain yang melebihi nominal Rp. 1 milyar dengan penetapan kualitas dapat didasarkan pada prospek usaha, kinerja usaha, dan kemampuan membayar. Adapun untuk plafon di atas Rp. 5 milyar tetap mengacu pada Peraturan Bank Indonesia. 
Selain itu, perlakuan khusus yang diberikan sangat meringankan/longgar bila dibandingkan dengan ketentuan dalam hal kredit bagi daerah tertentu dengan penetapan kualitas dapat didasarkan pada ketetapan pembayaran pokok/atau bunga.

2. Rektrukturasasi Kredit

Adapun perlakuan khusus dalam rektrukturisasi kredit adalah bagi kualitas kredit bagi bank umum maupun BPR yang diresktrukturisasi ditetapkan lancar sampai jangka waktu 3 tahun dan rekstrukturisasi dapat dilakukan baik sebelum dan sesudah terjadinya gempa.

Hal ini sangat berbeda saat keadaan normal yang mengacu pada pada PBI Nomor 14/15/PBI/2012 tentang Penilaian Kualitas Aset Bank Umum. Restukturisasi kredit dapat dilakukan dalam keadaan normal bila debitur mengalami kesulitan mengalami pembayaran pokok dan/atau bunga kredit dan debitur masih memiliki prospek usaha yang baik dan dinilai mampu memenui kewajiban setelah direkstruktisasi. Setelah gempa, kebijakan yang diterapkan adalah seluruh kredit dapat melakukan redistrukturisasi meski pada saat sebelum gempa tidak mengalami kesulitan dalam pembayaran pokok dan/atau bunga.

Selain itu, dalam keadaan normal disebutkan bahwa kualitas kredit setelah direkstrukturisasi paling tinggi sama dengan kualitas kredit sebelum direstrukturisasi sepanjang debitur belum memenuhi kewajiban pembayaran angsuran pokok secara berturut-turut selama 3 kali periode secara berturut-turut dan dapat meningkat paling tinggi 1 (satu) tingkat dari kualitas kredit sebelum dilakukan restrukturisasi setelah debitur memenuhi kewajiban pembayaran angsuran secara berturut-turut selama 3 kali periode sesuai waktu yang diperjanjikan. Hal ini sangat berbeda dengan perlakuan khusus yang diberikan yaitu langsung dikategorikan lancar sejak 3 tahun setelah bencama.

Adapun skema restrukturisasi yang diberikan kepada nasabah dalam bentuk perpanjangan jangka waktu pinjaman, penundaan angsuran, dan penurunan suku bunga. Dasar kebijakan tersebut dengan memperhatikan kondisi rumah yang telah terkategori sesuai yang telah ditetapkan oleh bank dengan jangka waktu maksimal 3 tahun.

Adapun untuk penundaan angsuran diberikan oleh bank kepada nasabah dengan melihat kondisi tempat tinggal nasabah dengan kategori rusak ringan, rusak sedang, dan rusak parah. Tingkatan jangka waktu penundaan pembayaran memiliki tingkatan yaitu 3 bulan, 6 bulan, dan 12 bulan yang diterapkan pasca dikeluarkannya perlakuan khusus oleh Dewan Komisioner OJK. Bila nasabah masih tidak mampu melakukan pembayaran secara normal sesuai jangka waktu yang telah disepakati maka akan dipertimbangkan kembali, mengingat usaha nasabah sebagai sumber pokok penghasilan masih belum berjalan secara normal.

Resktrukturisasi dalam penurunan suku bunga diberikan kepada nasabah bila nasabah ingin tetap melakukan pembayaran dengan dasar rumah dan usaha tidak terdampak dan masih memiliki kemampuan untuk membayar, akan tetapi jangka waktu untuk penurunan suku bunga ditetapkan oleh bank.

3. Pemberian Fasilitas Kredit dan/atau Penyediaan Dana Lain Baru

Adapun pemberian kredit baru terhadap debitur yang terkena dampak maka bank dapat memberikan kredit bagi debitur yang terkena dampak bencana alam dan penetapan kualitas kreditnya dilakukan secara terpisah dengan kualitas kredit yang telah ada sebelumnya, yaitu: 
a. untuk kredit atau pembiayaan dan/atau penyediaan dana lain yang diberikan setelah terjadinya bencana alam dengan plafon sampai dengan Rp5.000.000.000,00 (lima miliar rupiah), penetapan kualitas kredit atau pembiayaan mengacu pada ketentuan hanya didasarkan pada ketepatan pembayaran pokok dan/atau bunga.

b. untuk kredit atau pembiayaan dan/atau penyediaan dana lain yang diberikan setelah terjadinya bencana alam dengan plafon lebih dari Rp5.000.000.000,00 (lima miliar rupiah), penetapan kualitas kredit atau pembiayaan mengacu pada ketentuan peraturan perundang-undangan mengenai penilaian kualitas aset bank umum atau ketentuan Otoritas Jasa Keuangan yang mengatur mengenai penilaian kualitas aset bank umum syariah dan unit usaha syariah.

Dalam pelaksanaan pemberian kredit baru bagi nasabah, bank sangat berhati-hati dalam memutuskan pilihan. Salah satu indikator yang ditetapkan oleh bank adalah kualitas kredit sebelum bencana terjadi yang masuk dalam kategori lancar.

\section{Tinjauan Ekonomi Syariah terhadap Kebijakan Penangan Kredit Bermasalah bagi Nasabah}

Banyak kasus kredit bermasalah terjadi diakibatkan oleh bencana alam sehingga posisi perbankan mengalami dilema. Hal demikian terjadi disebabkan bank harus mampu survive dengan tidak menyalahi aturan yang berlaku, namun disisi lain bank juga dituntut untuk dapat memberikan rasa kemanusiaan kepada nasabah yang tertimpa musibah.

Dalam kasus kredit macet akibat bencana termasuk dalam kondisi force majeure, yang merupakan unsur ketidaksengajaan oleh debitur yang memiliki keinginan untuk membayar tetapi tidak mampu. Dalam keadaan memaksa ini, terjadi peristiwa yang tidak terduga yang terjadi di luar kesalahan para debitur setelah terjadinya sebuah perjanjian (akad) sehingga peristiwa tersebut menghalangi debitur untuk memenuhi prestasinya sebelum dinyatakan lalai dan oleh karenanya debitur tidak dapat disalahkan untuk tidak menanggung risiko atas peristiwa tersebut (Delaume, 1971). Terdapat alasan yang menjadikan para debitur bencana dapat dikategorikan sebagai force majeure, yaitu tidak terpenuhinya prestasi yang disebabkan oleh peristiwa yang dapat membinasakan hingga memusnahan objek perikatan; terdapat penyebab di luar kesalahan debitur yang disebabkan oleh peristiwa yang mampu menghalangi debitur untuk berprestasi; dan faktor penyebab itu atau peristiwa tersebut tidak terduga sebelumnya dan tidak mungkin untuk dipertanggungjawabkan kepada debitur (Silber, 2010).

Melihat kondisi pasca bencana, pemerintah telah berupaya meringankan beban masyarakat yang terdampak bencana. Salah satu upaya pemerintah adalah pemberian perlakuan khusus kepada nasabah yang terdampak bencana. Perlakuan khusus tersebut dikeluarkan tidak begitu lama setelah bencana terjadi. Hal ini memberikan pemahaman peran pemerintah dalam menjalankan tugasnya. Pemerintah wajib mempunyai kemampuan untuk mengontrol setiap bencana yang terjadi yang meliputi perencanaan dan persiapan respons bencana, bantuan koordinasi, kebijakan rekontruksi dan mengatasi masalah populasi. Pemerintah dengan sebuah pengembangan program manajemen bencana dapat melakukan koordinasi yang baik. Berdasarkan pada hukum kemanusiaan internasional, pemerintah nasional merupakan pihak utama yang harus merespon bencana alam (Aksa, 2015). Prinsip khilafah dalam ekonomi Islam menjamin perekonomian berjalan dengan baik.

Berdasarkan pembahasan pada kebijakan penanganan kredit bermasalah pasca bencana pada bank konvensional, perlakuan khusus tersebut diperuntukkan kepada 
nasabah yang terdampak bencana sehingga menyulitkan nasabah agar tetap pada kualitas kredit dalam kategori lancar. Nampak kebijakan tersebut memberikan keringanan bagi nasabah dengan tidak membeda-bedakan perlakuan kepada nasabah. Setiap nasabah dibolehkan untuk mengajukan resktrukturisasi dengan persyaratan nasabah terdampak bencana dan mendatangi pihak perbankan dan memberikan informasi terkait dampak bencana dan mengemukakan alasan pengajuan resktrukturisasi. Dalam hal ini, OJK memberikan aturan dan petunjuk kepada bank konvensional agar memberikan perlakuan kepada nasabah yang terdampak bencana.

Dalam sudut pandang ekonomi Islam, salah satu prinsip ekonomi Islam adalah keadilan yang dimaknai di dalam persamaan hukum yang di maksudkan di sini ialah setiap orang harus diberlakukan sama didepan hukum yang berarti tidak boleh membedabedakan antara golongan satu dengan golongn yang lain, tidak boleh mendiskriminasi terhadap seseorang didepan hukum dengan alasan apapun. Setiap orang harus diberlakukan yang sama adilnya dengan orang lain (P3KI UII Yogyakarta \& Bank Indonesia, 2012).

Selain itu, perlakuan khusus diberikan oleh bank kepada dengan berbagai opsi. Opsi yang ditawarkan kepada nasabah yaitu bila nasabah menganggap masih kesulitan dalam pembayaran kredit, maka nasabah dibolehkan untuk tetap membayar kredit bila nasabah merasa mampu membayar dan pembayaran kredit dilakukan tanpa disertai bunga dan hanya angsuran pokok yang jangka waktunya ditentukan oleh bank yaitu 3 bulan.

Adapun bagi nasabah yang tidak mampu membayar kredit maka diberikan keringanan yaitu menunda pembayaran dengan memberikan dokumentasi kondisi rumah kepada bank dan mengisi formulir penundaan yang kemudian bank menentukan jangka waktu diberikan. Tingkatan jangka waktu terkait penundaan pembayaran didasarkan kepada kondisi rumah. Kondisi rumah nasabah terdampak bencana memiliki 3 kategori, yaitu rusak ringan, rusak sedang, dan rusak berat. Realitas yang terjadi adalah penentuan tingkatan jangka waktu terkadang tidak sesuai dengan kondisi riil rumah pasca gempa. Dalam Islam, keutamaan dalam menunda pembayaran merupakan salah satu etika dalam utang-piutang. Hal tersebut sebagaimana diungkapkan oleh Allah SWT dalam QS. Al Baqarah (2): 280.

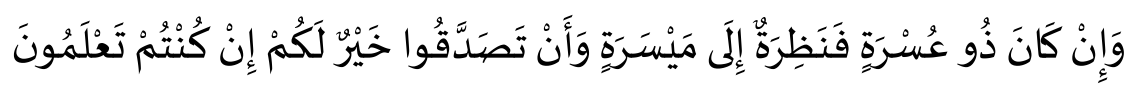

dan jika (orang yang berhutang itu) dalam kesukaran, maka berilah tenggang waktu sampai dia memperoleh kelapangan. dan jika menyedekahkan, itu lebih baik bagimu, jika kamu mengetahui.

Begitu pula dalam hadis disebutkan keutamaan dalam pemberian tenggang waktu bagi yang sulit melunasi.

$$
\text { مَنْ أَنََْرَ مُعْسِرًا أَوْ وَضَتَعَ عَنْهُ، أَظَلَّهُ اللَهُ فِي ظِلِّهِ }
$$

Barangsiapa memberi tenggang waktu bagi orang yang berada dalam kesulitan untuk melunasi hutang atau bahkan membebaskan hutangnya, maka dia akan mendapat naungan Allah (HR. Muslim)

Hadirnya perlakuan khusus dapat meringankan beban bagi nasabah, namun terdapat beberapa dari nasabah memanfaatkan momentum ini untuk mendapatkan penundaan pembayaran dengan memanipulasi data, sehingga perolehan jangka waktu 
penundaan tidak relevan padahal memiliki kemampuan untuk membayar setiap bulannya. Hal tersebut dilakukan dengan dalih nilai uang akan semakin menurun/spekulasi dan menghindari pembayaran. Perilaku yang demikian tentunya tidak mencerminkan adab dalam pinjam meminjam.

Hukum menunda pembayaran hutang tidak haram apabila orang yang berhutang memang benar-benar belum mampu membayarnya atau ia telah mampu membayarnya namun masih berhalangan untuk membayarnya semisal uang yang ia miliki belum berada ditangannya atau alasan-alasan lain yang dibenarkan agama (AlZarqani, 2003).

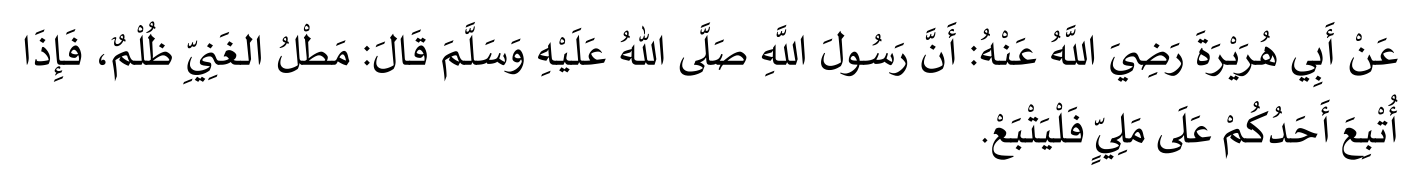

Dari Abi Hurairah ra: sesungguhnya Rasululah saw berkata: Penundaan pembayaran hutang yang dilakukan oleh orang yang kaya adalah kezaliman. Apabila seseorang diantara kalian dipindahkan kepada orang yang kaya maka hendaknya dia mengikuti. (HR. Bukhari)

Namun perlakuan khusus kepada nasabah tampak tidak adil dangan mencolok dalam kategori rumah rusak berat dengan indikator rumah tidak dapat ditinggali sebagaimana mestinya, akan tetapi terdapat banyak nasabah yang memiliki rumah rusak berat disertai dengan kondisi tanah yang tidak memungkinkan untuk membangun rumah kembali, sebagai contoh di lokasi yang merupakan zona yang ditetapkan sebagai zona yang tidak diperuntukkan untuk pemukiman. Perlakuan untuk penundaan pembayaran diberlakukan sama dengan nasabah yang rumahnya berada pada zona hijau atau zona aman yang dapat dijadikan sebagai wilayah pemukiman.

Hal ini merupakan bentuk ketidakadilan bagi nasabah yang rumah dan usahanya tidak terselamatkan. Rumah merupakan kebutuhan pokok bagi manusia namun untuk memenuhi kebutuhan, manusia melakukan usaha sesuai dengan kompetensi dan minatnya. Namun, bila usaha yang dimiliki sebagai penopang kebutuhan hidup tak mampu lagi memenuhi kebutuhan akibat terdampak bencana tentunya sangat miris bila membandingkan dengan nasabah yang rumahnya termasuk dalam kategori rusak berat namun dapat dibangun kembali. Hal ini diperparah lagi dengan tetapnya utang terhadap lembaga perbankan meskipun telah disetujuinya penundaaan pembayaran. Bagi nasabah yang terdampak bencana cukup berat tentunya harus memulai segera usaha baru dengan tetap memikirkan upaya membayar kredit bila jangka waktu penundaan pembayaran telah selesai dan hal ini cukup menyulitkan.

Bank sebagai lembaga yang berorientasi profit yang menjadikan kredit bermasalah/Non Performing Loan merupakan indikator kesehatan bank serta memberikan dampak bagi kinerja bank. Bank butuh waktu dan cara tersendiri untuk mengembalikan kondisi agar kembali dalam kondisi normal lagi. Kredit NPL yang diakibatkan bencana alam dalam jumlah besar akan memberikan efek terhadap dunia perbankan. Dengan demikikian, bank dan para debitur sangat menunggu keputusan dan regulasi yang tepat dan cepat guna kepastian hukum dalam penanganannya dengan memperhatikan kepentingan dan kondisi bersama perbankan dan kepentingan nasabah. Apalagi bank yang berstatus BUMN akan memilih hapus tagih, maka akan dianggap merugikan keuangan negara. 
Dalam beberapa kasus kredit macet perbankan akibat bencana alam yang pernah terjadi di Indonesia, pemerintah bekerja sama dengan BI dan OJK (Otoritas Jasa Keuangan), telah memberikan arahan agar diadakan aturan tersendiri tentang kebijakan bantuan perbankan akibat bencana alam, baik mengenai penjadwalan ulang, pengajuan pinjaman baru maupun penghapusan hutang. Hanya saja, keputusan yang pernah diterapkan oleh pemerintah sebagai pemegang policy, antara satu kasus dengan kasus lain terlihat ambigu dikarenakan pemerintah memberikan dan menerapkan keputusan yang berbeda-beda. Hal ini bisa dilihat pada ketidaksamaan kebijakan yang diberikan oleh pihak otoritas perbankan kepada para nasabah antara korban banjir di Manado dan erupsi Gunung Sinabung di Karo dengan kebijakan korban letusan Gunung Merapi di Jawa Tengah (Adlan, 2016). Perbedaan penerapan kebijakan tersebut membingungkan dan menimbulkan rasa tidak ketidakadilan bagi sebagian nasabah korban bencana terkhusus pengusaha UMKM yang menganggap keputusan tersebut tidak berpihak kepada mereka.

Hukum Islam diciptakan dan dilaksanakan secara menyeluruh tidak lain adalah bertujuan demi kemaslahatan dan kesejahteraan manusia di dunia dan akhirat. Dalam upaya mencapai tujuan tersebut maka hukum Islam mempunyai beberapa prinsip, yaitu: 1) memberikan kemudahan dan meniadakan kesulitan, 2) menyedikitkan beban, dan 3) menempuh jalan pertahapan.

Apabila kondisi seseorang yang berutang dalam kesulitan dan dalam keadaan ketidakmampuan, maka orang yang berpiutang dianjurkan memberikan kelonggaran dengan menunggu sampai orang yang berpiutang mampu untuk membayar utangnya. Islam menganjurkan untuk melunasi hutang jika sudah sanggup membayarnya agar terlepas dari tanggung. Bila seseorang mampu membayar hutang tetapi tidak melakukannya maka dikategorikan telah bertindak zalim. Namun lain halnya bila orang yang berhutang tersebut dalam keadaan kesulitan atau belum mampu melunasi hutangnya, maka Islam menganjurkan kreditur untuk memberikan penundaan pembayaran, atau dimungkinkan kreditur dapat memaafkan dan membebaskan debitur serta menganggap hutang tersebut sebagai sedekah atau zakat wajib karena orang yang berhutang berhak menerima zakat (al-Maragi, 1987). Asas kemaslahatan baik perorangan maupun masyarakat dalam urusan muamalah adalah asas yang paling pokok dalam fiqh oleh sebab itu hukum harus berkisar dari illat-nya. Selain itu, maksud diturunkan hukum tahap demi tahap adalah agar seiring dengan kemaslahatan manusia itu sendiri (Shiddiqi, 1997).

Untuk itu langkah yang harus dilakukan adalah bank wajib mendata jenis kredit dan nasabah yang terdampak akibat bencana alam sehingga diperolehnya pengklasifikasian nasabah secara jelas sebagai acuan penerapan keputusan OJK dan bank. Dengan demikian kebijakan bagi nasabah korban bencana dapat diperlakukan secara berbeda, utamnya antara nasabah kredit konsumtif dengan kredit usaha produktif, antara skala usaha kecil dan menegah dengan usaha skala besar, antara kreditur yang masih mampu bila diberikan penundaan dengan kreditur yang tidak mampu untuk meneruskan usahanya.

\section{KESIMPULAN}

Segala yang terjadi di dunia ini merupakan kehendak-Nya, sehingga manusia harus berserah diri dan bersangka baik atas segala yang terjadi. Penanganan kredit bermasalah masih terdapat beberapa hal yang perlu diperjelas utamanya bagi hapus buku 
dan hapus tagih yang tidak diatur dalam Peraturan OJK Nomor 45/POJK.03/2017 tentang Perlakuan Khusus terhadap Kredit atau Pembiayaan bagi Daerah Tertentu di Indonesia yang Terkena Bencana Alam. Selain itu, penetapan kualitas kredit dan resktrukturisasi dengan masa 3 tahun dalam perlakuan khusus bagi daerah yang terkena bencana alam dalam Peraturan OJK sangat terlalu dini untuk ditetapkan mengingat dampak bencana alam bagi setiap nasabah berbeda-beda dan memungkinkan sebagian nasabah melakukan iktikad kurang baik dengan memanfaatkan situasi untuk menghindari pembayaran. Hal ini disebabkan karena tidak adanya indikator lengkap nasabah yang terdampak bencana.

\section{REFERENSI}

Adlan, M. Aqim. 2016. Penyelesaian Kredit Macet Perbankan dalam Pandangan Islam: Tinjauan Regulasi Kasus Kredit Macet Akibat Bencana Alam. Jurnal An-Nisbah, Volume 2, No. 2: 145-186.

Albanese, Claudio, Damiano Brigo, and Frank Oertel. 2013. Restructuring Counterparty Credit Risk. International Journal of Theoretical and Applied Finance, Volume 16 (2): 1-29.

Al-Maraghi, Ahmad Musthofa. 1987. Tarjamah Tafsir al-Maraghi, alih bahasa M. Thalib. Bandung: CV Rosda Karya.

al-Nisaburi, Muslim bin al-Hajjaj bin al-Muslim al-Qusyairi. T.th. Sahih Muslim. Juz IV; Beirut: Dar al-afaq.

al-Syaibani, Abu 'Abdullah Ahmad bin Muhammad bin Hanbal bin Hilal bin Asad. 1995. Musnad al-Imam Ahmad bin Hanbal. Juz. XXXVII . Cet. I;Beirut: Mu'sasah alRisalah.

al-Zarqani, Muhammad bin 'Abd al-Baqi bin Yusuf. 2003. Syarh al-Zarqani 'Ala Muwatha al-Imam Malik. Juz III; Cet. I; al-Qahirah: Maktabah al-Saqafah alDainaih.

Anandarajan, M. Igbaria, M. \& Anakwe, U. 2000. Technology Acceptance in the Banking Industry: A Perspective from a Less Developed Country. IT \& People, Volume 13(4): 298-312. doi:10.1108/095938400103 59491

Arif, Muhammad. 1985. Toward a Definition of Islamic Economics: Some Scientific Considerations. Journal of King Abdulaziz University: Islamic Economics, Volume (2): 79-93.

Asikim, Zainal. 2016. Pengantar Hukum Perbankan Indonesia. Jakarta: Rajawali Press.

Awalia, Vidia Reski. Mappamiring. Andi Nuraeni Aksa. 2015. Peran Pemerintah dalam Menanggulangi Resiko Banjir di Kabupaten Kolaka Utara. Otoritas: Jurnal Ilmu Pemerintahan, Vol. 5 (2): 202-213.

Aziz, Farooq. Muhammad Mahmud. 2009. Islamic Economics system In the Eyes of Maulana Maududi-An Analysis. Indus Journal of Management \& Social Science (IJMSS), Department of Business Administration, Volume 3 (2): 45-50.

Biety, Monnie. Karen Cak Nerderkohr. 2008. Model Regulation for Credit Unions. USA: World Council of Credit Unions.

Chapra, M. Umer. 1995. Islam and The Economic Challenge. Riyadh: International Islamic Publishing House. 


\section{Kebijakan Penanganan Pembiayaan Bermasalah pada Bank Syariah dan Konvensional}

Perspektif Ekonomi Syariah Pasca Bencana di Sulawesi Tengah

Chatamrrasjid, Ais. 2006. Hukum Perbankan Nasional Indonesia. Jakarta: Kencana.

Clair, Robert T., and Paula Tucker. 1993. Six Causes of The Credit Crunch. Federal Reserve Bank of Dallas Economic, Review 3.

Crawford, Vincent P. 1987. International lending, Long-Term Credit Relationships, and Dynamic Contract Theory. International Finance Section, Department of Economics, Princeton University, 1987.

Dendawijaya, Lukman. 2005. Manajemen Perbankan. Jakarta: Ghalia Indonesia.

Departemen Agama RI. 2010. Al-Qur'an dan Terjemahnya. Bandung: CV Penerbit Diponegoro.

El-Gamal, Mahmod A. 2006. Islamic Finance; Law, Economics and Practise. Cambridge: Cambridge University Press.

Emzir. 2010. Metode Penelitian Kualitatif: Analisis Data. Jakarta: PT. Rajagrafindo Persada.

Franks, Julian \& Oren Sussman. 2005. Financial Distress and Bank Restructuring of Small to Medium Size UK Companies. Review of Finance, Volume 9 (1): 65-96.

Gazali , Djoni S. Rachmadi Usman. 2012. Hukum Perbankan. Jakarta: Sinar Grafika.

Georgievska, A., Et Al. 2008. Sovereign Rescheduling Probabilities in Emerging Markets: A Comparison with Credit Rating Agencies' Ratings. Journal Of Applied Statistics, Vol. 35 (9): 1031-1051.

Hamidu, Novia P. 2013. Pengaruh Kinerja Keuangan terhadap Pertumbuhan pada Perbankan di BEI. Jurnal EMBA, Volume 1 (3): 711-721.

Haneef, Shahbaz. Tabassum Riaz, et.al. 2012. Impact of Risk Management on NonPerforing Loans and Profitability of Banking Sector of Pakistan. International Journal of Business and Social Change, Volume 3 (7): 307-315.

Hodgman, Donald R. 1960. Credit Risk and Credit Rationing. The Quarterly Journal of Economic, Volume 74 (2): 258-278.

Ibn Isma'il, Abu 'Abdillah Muhammad. 1987. al-Jami’al-Sahih. Juz. III, Cet. III; Beirut: Dar Ibn Katsir, 1407 H/1987 M.

Kasmir. 2014. Dasar-Dasar Perbankan. Jakarta: PT RAjaGrafindo Persaja, 2014.

Lanoie, Paul, Lemarbre, Sylvain. 1996. Three Approaches to Predict The Timing and Quantity of LDC Debt Rescheduling. Applied Economics, Vol. 28 (2): 241-246.

Maarif, Syamsul. Pikiran dan Gagasan Penanggulangan Bencana di Indonesia. Jakarta: BNPB, t.th.

Mackenzie, Donald. 2011. The Credit Crisis as a Problem in The Sociology of Knowledge. American Journal of Sociology. Volume 116 (6): 1778-1841.

Manan, Muhammad Abdul. 1980. Islamic Economics, Theory and Practice. India: Idarah Adabiyah. 


\section{Syaakir Sofyan}

Marchesi, Silvia. 2003. Adoption of an IMF Programme and Debt Rescheduling; an Empirical Analysis. Journal of Development Economics, Volume 70 (2): 1-34.

Moleong, L. J. 2014. Metode Penelitian Kualitatif. Bandung: PT. Remaja Rosdakarya.

MS, Kimberly Beaton. Alla Lyrvoda. 2016. Non Performing Loans in the Eccu. Washington DC: International Monetery Fund.

Nabi, Nasir. 2016. The Economic Thought of Khursid Ahmad. Turkish Journal of Islamic Economics. Volume 3 (2): 1-11.

Naqvi, Syed Nawab Haider. 2009. Menggagas Ilmu Ekonomi Islam, terj. M. Saiful Anam dan Muhammad Ufuqul Mubin. Yogyakarta: Pustaka Pelajar.

Pramudhiarta, Narwawi; Permanasari, Adhistya Erna; \& Ari Cahyono. 2014. Penerapan Knowledge Management System Berbasis Web sebagai Sistem Pendukung Pengambilan Keputusan (DSS) dalam Pengurangan Risiko Bencana di Indonesia. Jurnal Dialog Penanggulangan Bencana, Vol 5 (1): 1-64.

Pusat Pengkajian dan Pengembangan Ekonomi Islam (P3KI) UII Yogyakarta dan Bank Indonesia 2012. Ekonomi Islam. Jakarta: Rajawali Press.

Rivai, Veithzal. Andria Permata Veithzal. 2006. Credit Management Handbook: Teori, Konsep, Prosedur, dan Aplikasi Panduan Praktis Mahasiswa, Bankir, dan Nasabah. Jakarta: PT. RajaGrafindo Persadam.

Saba, Irum. Rehana Kouser. Muhammad Azeem. 2012. Determinants of Non Performing Loans: Case of US Banking Sector". The Romanian Economic Journal, Volume 44 (6): $125-136$.

Salas, Vicente. Saurina. Jesus. 2002. Credit Risk in Two Institutional Regimes: Spanish Commercial and Savings Banks. Journal of Financial Services Research. Volume 22 (3): 203-224.

Santoso, Wimbih. Kredit Bermasalah Pascagempa di Sulteng diperkirakan Rp. 4 triliun, Antara Sulteng, 18 Oktober 2018. Diakses pada tanggal 21 September 2019 dari https://sulteng.antaranews.com/berita/44862/kredit-bermasalah-pascagempa-disulteng-diperkirakan-rp4-triliun

Shiddiqi, Nurzaman. 1997. Fiqh Indonesia Penggagas dan Gagasannya. Yogyakarta: Pustaka Pelajar.

Silber, Norman I. 2010. Debts. Disasters, and Delinquencies: A Case fir Placing a Mandatory Force Majure Provision it Consumer Credit Agreements. NYU Review of Law \& Social Change. Volume 34: 760-792.

Suadi, Amran. 2018. Penyelesaian Sengketa Ekonomi Syariah: Penemuan dan Kaidah Hukum. Jakarta: Prenamedia Group.

Sugiyono. 2009. Metode Penelitian Kuantitatif Kualitatif dan $R \&$ D (Cet. VI; Bandung: Alfabeta.

Sutarno. 2003. Aspek-Aspek Hukum Perkreditan pada Bank. Bandung: Alfabeta.

Triandaru, Sigit. 2006. Bank dan Lembaga Lain. Yogyakarta: Salemba Empat. 
Kebijakan Penanganan Pembiayaan Bermasalah pada Bank Syariah dan Konvensional Perspektif Ekonomi Syariah Pasca Bencana di Sulawesi Tengah

Yildirim, H. Semih and George C. Philippatos. Restructuring. 2007. Consolidation and Competition in Latin American Banking Markets. Journal of Banking \& Finance. Volume 3 (3): 629-639.

Zaman, S. M. Hasanuz. 1984. Definition of Islamic Economics تعريف الاقتصاد الإسلاكسي ,. Journal of Research in Islamic Economics, King Abdulaziz University, Islamic Economics Institute, Volume 1 (2).

Zhang, Dayong. Jing Cai. David G. Dickinson. Ali M. Kutan. "Non Performing Loan, Moral Hazard and Regulation of the Chinese Commercial Banking System". Journal of Banking \& Finance. Volume 63: 48-60. 